\title{
STUDY OF QUESTIONS OF ANTIKOOL PTOPHYLACTIC NUTRITION OF POPULATION WITH THE USE OF ADAPTANGENES OF ANIMAL ORIGIN
}

Korshunova N.V., Yurechko O.V., Voitus L.V.

Amur State Medical Academy Blagoveshchensk Russian Federation

Abstracts For easening of implementation of mechanisms of adaptation to cold influence on humans, they use pharmacological agents; however, the scope of these foods is limited. Human nutrition focuses on the use of adaptangenes of traditional medicine of animal origin, such as pants of dappled deer and reindeer. As the result of experimental research they got new data on exclusion of toxicity of researched adaptangenes, antioxidant properties actoprotective effect of cold influence on organism were identified. Key words Pants, cold influence, antioxidant effect, actoprotective influence. The most important pathogenic climatological environmental factor influencing on the population of Russian Federation, especially in the North and Far East is cold. Adaptation to cold influence is long process; morphological changes are stipulated by the deterioration of cell membranes and activation of lipid peroxidation etc. For easening of adaptation reactions to cold, they use the means from pants of dappled deer and reindeer influencing human organism softly and harmonically without side effects (Brachman 1974).

The goal and task of research was scientific-methodical ground of nutritive use of pants' foods for increasing of human organism' cold-resistance.

Materials and methods

Research on exclusion of toxicity of foods from pants were conducted in accordance with generally accepted methodical approaches (I.V. Sanozkii and coauthors 1979). For study of antioxidant features of foods from pants, they selected biochemical methods letting evaluate the participation of researched foods in the processes of peroxidized lipid oxidation (POL). Physical working capacity was identified according to the swimming time, working capacity of experimental rats on tertiary. The study of adaptive reactions of animals towards cold were conducted with the use of model of long cold influence with the use of climatic cell of the firm "Fentron" - GDR (V.A. Dorovskih 1987). The researched elements of pants are safe according to the criteria of common-toxic influence. They respond to the demands of safety according to ecological and hygienic concept of human nutrition. The following foods from pants are increasing the stability of animals towards fatigue in conditions of adaptation to coldness. They are effective as antioxidant means for prevention of pathogenic influence of low temperatures in the periods of long freeze. That is adaptogenic elements from pants are recommended for use in human nutrition for correction of cold stress on organism.

\section{References}

1. Brachman I.I. Pantocrinum. Pharmacology and curative effect.// Moscow, 1974. - p. 7-9, 18, 34, 35, 38-39.

2. Dorovskih V.A. Pharmacological correction of cold influence during experiment//M.D. research paper, 1987. - 290

pages.

3. Sanozkii I.V. and coauthors. Methods of defining and classification of toxicity// Criteria of harmness in hygiene and toxicology in the evaluation of chemical compounds. - Moscow, 1975. - p.55.

Translator - senior assistant AGMA - Korshunova D.V. (M.A. linguistics AMGU)

Email address Korshunova Natalia Vladimirovna - kaf_gigieny@amursma.su

\section{INHIBITORY EFFECT OF COMBINATION OF DOXORUBICIN HYDROCHLORIDE AND LIGUSTRAZINE ON PROLIFERATION OF HELA CELLS AND HEP-G2 CELLS Meng-yuan Li1,Bei Zhang , Xue-Ying Yan*}

School of Pharmacy, Heilongjiang University of Chinese Medicine, P.R.China

* Corresponding author:

Xue-Ying Yan, Address: Heping Road 24, Harbin 150040, School of Pharmacy, Heilongjiang University of Chinese Medicine, P.R.ChinaE-Mail: 1192416276@qq.com

Abstract Objective: To study the effect of doxorubicin hydrochloride (DOX) combined with ligustrazine (TMP) on the proliferation of Hela cells and Hep-G2 cells, and evaluate the inhibitory effect of combination therapy on the proliferation of tumor cells. Methods: MTT assay was used to detect the effects of TMP, DOX and combination of both on the proliferation of Hela cells and Hep-G2 cells, respectively. Results: In the selected concentration range, the inhibitory rate of Hela cells and Hep-G2 cells was inhibited in a dose-dependent manner. The combination of TMP and DOX in the treatment of Hela cells showed a good additive effect, and the treatment of Hep-G2 cells had a certain synergistic effect, when the ratio of tetramethylpyrazine to doxorubicin was 5: 1,2.5: 1 and 1.25: 1. The concentration of DOX in the range of $5 \sim 20 \mathrm{mg} / \mathrm{L}$ and the concentration of TMP in the range of $25 \sim 100 \mathrm{mg} / \mathrm{L}$. Conclusion: The combination of DOX and TMP can inhibit the proliferation of Hela cells, Hep-G2 cells, promote cell apoptosis. Key words: MTT; effect of drugs combination ;synergistic.

Objective

In this study, it uses a combination of chemotherapy(DOX) and traditional Chinese medicine(TMP)[1-2], after pretest screening to determine the concentration of two kinds of drugs, and according to it set a different proportion of groups, Which provides a new idea for the determination of the dosage range and the proportion of the combination therapy, which provides a theoretical basis for the rational application of clinical combination therapy.

Materials and Method

Materials: Adriamycin hydrochloride (CAS:25316-40-9, Beijing Huafeng Bo Technology Co.Ltd.); Tetramethylpyrazine (CAS: 1124-11-4, Nanjing Dao Sifu Biotechnology Co., Ltd.); DMEM mediumwas purchased from Gibco Chemical Co. (Carlsbad, CA, USA);Serum (Shanghai ExCell Biological Products Co., Ltd.) Method:MTT assay was used to detect the inhibitory effect of DOX, TMP and different proportions of two drugs on the proliferation of Hela cells and Hep-G2 cells.100 $\mu$ l of Hela and Hep-G2 cells in logarithmic growth phase were placed in 96-well plates.The cells were cultured for $24 \mathrm{~h}$ in a $5 \% \mathrm{CO} 2$ incubator.One group was added to the cell suspension without drugs as a control.Then we added different concentrations of TMP and DOX, each concentration of 5wells.After cultured for $48 \mathrm{~h}, 10 \mu \mathrm{l}$ of MTT solution was added to each welland culture was continued for $4 \mathrm{~h}$. $150 \mu \mathrm{l}$ of DMSO was added to each well.The OD valuewas measured at $490 \mathrm{~nm}$.Inhibition 